Arija Meikalisa, Dr. iur., Professor,

University of Latvia, Latvia,

Kristine Strada-Rozenberga, Dr. iur., Professor,

University of Latvia, Latvia

\title{
DETENTION ON REMAND: AN UPDATED VIEW OF THE CURRENT PROBLEMS OF APPLICATION AND IMPACT ON THE OUTCOME OF CRIMINAL PROCEEDINGS
}

\begin{abstract}
Summary
Detention ${ }^{1}$ in criminal proceedings in Latvia, similarly to other countries, is the most severe preventive coercive measure, which is used to ensure the legal course of criminal proceedings and reaching the purpose of criminal proceedings. The issue of the practical impact of applied detention on the outcome of criminal proceedings has almost never been examined. The article's main focus is on the prevalence of applying detention in Latvia, the practical issues in application, as seen by parties involved in the practice of law enforcement, as well as the impact of detention on the final outcome of criminal proceedings - probable exoneration of the detained person in the course of proceedings, the type of punishment and sanction applied to the person. On the basis of available statistical information, analysis of court rulings and a survey of professionals involved in the application of criminal procedure, an insight is provided in some aspects of applying detention in practice that either are or are not recognised in practice, the frequency of application; likewise, the impact on the final outcome of criminal proceedings in Latvia is analysed. The research has led to the finding that making of high-quality conclusions is hindered by lack or incompleteness of statistical and other publicly accessible information, whereas the outcomes of the survey of professionals prove that opinions differ significantly, depending on affiliation with a particular group of respondents. In characterising the general trends, it is concluded that there is a trend of decreasing in the prevalence of applying detention in Latvia, the most relevant practical problem in the application of detention is the insufficient substantiation in the proposals to apply detention, also, certain correlation can be discerned between the fact that a person had been detained and the final outcome of criminal proceedings, in particular, with respect to the type of punishment and sanction.
\end{abstract}

Keywords: pre-trial detention, detention on remand, overuse of detention, practical problems in the application of detention, impact of the pre-trial detention on the outcome of criminal proceedings

1 This article describes detention, which is applied in pre-trial and trial proceedings to persons, with respect to whom the final ruling in criminal proceedings has not yet entered into effect. 


\section{Introduction}

In Latvia, legal regulation on detention as one of the coercive measures linked to the deprivation of liberty, is included in Chapter 15 of the Criminal Procedure $\mathrm{Law}^{2}$ (hereafter - CPL). Similarly to other countries, in Latvia detention is viewed as the most severe of security measures that is applicable to a suspect or an accused only if there is a valid opinion that other security measures will be unable to ensure an appropriate course of criminal proceedings. In 2015, the General Assembly of the Council of Europe, examining the matter of applying detention and adopting the resolution "Abuse of pretrial detention in States Parties to the European Convention on Human Rights"3, once again noted that application of detention as a coercive measure was admissible only as an exception. Likewise, it was recognised "that the laws of most Member States are generally in line with European Convention on Human Rights standards, but their application by the prosecutorial authorities and the courts is frequently not". Examination of the legal regulation on detention in Latvia allows recognising that, in general, it complies with the human rights standards set in Europe. Some relatively minor deficiencies can be identified in it, for example, uncertainty regarding the possibility to apply detention to persons, who have committed a less serious crime while being minors. Several proposals for improvements could be advanced for a discussion. For instance, expanding the application of bail as an alternative to detention, which, however, should be carefully considered, taking into account also the negative experience of other countries related to possible socially more unfair treatment of persons in a poorer financial situation ${ }^{4}$. Likewise, the matter of mitigating "the regime" of detention could be worth discussion because currently, in several aspects, it can be equalled to or is even more severe than that of a closed prison ${ }^{5}$. The opinion can be upheld that

2 Criminal Procedure Law. Available at: https://likumi.lv/ta/en/en/id/107820 [last viewed November 1, 2019].

3 Resolution 2077 (2015)1 Abuse of pretrial detention in States Parties to the European Convention on Human Rights Available at: http://semantic-pace.net/tools/pdf.aspx?doc=aHR0cDovL2Fzc 2VtYmx5LmNvZS5pbnQvbncveG1sL1hSZWYvWDJILURXLWV4dHIuYXNwP2ZpbGVpZD 0yMjIwNiZsYW5nPUVO\&xsl=aHR0cDovL3NlbWFudGljcGFjZS5uZXQvWHNsdC9QZGYv WFJIZi1XRC1BVC1YTUwyUERGLnhzbA==\&xsltparams=ZmlsZWlkPTIyMjA2 [last viewed November 1, 2019].

4 See, for example, Hopkins B., Bains C. H., Doyle C. Principles of pretrial release: reforming bail without repeating its harms. Journal of Criminal Law \& Criminology, Vol. 108, No. 4, 2018, pp. 679700. Available at: http://datubazes.lanet.lv:3537/ehost/detail/detail?vid=0\&sid=fbbfdcb6-01554e0b-93ac-60c8e2409ae3\%40sdc-v-sessmgr02\&bdata=JnNpdGU9ZWhvc3QtbGl2ZQ\%3d\%3d\#A $\mathrm{N}=135676927 \& \mathrm{db}=\mathrm{a} 9 \mathrm{~h}$ [last viewed November 1,2019$]$.

5 To compare, see: The restrictions set for a person at an institution for deprivation of liberty while serving the sentence - Sentence Execution Code of Latvia. Available at: https://likumi.lv/ ta/en/en/id/90218 [last viewed November 1, 2019]; Internal Regulations of an Institution for Deprivation of Liberty, Available at: https://likumi.lv/ta/id/136495-brivibas-atnemsanas-iestadesieksejas-kartibas-noteikumi [last viewed November 1, 2019]. The restrictions set for a person at an institution for deprivation of liberty while in detention - Law On the Procedures for Holding under Arrest. Available at: https://likumi.lv/ta/en/en/id/138990 [last viewed November 1, 2019]. Internal Regulations of a Remand Prison. Available at: https://likumi.lv/ta/id/167184-izmeklesanas-cietuma-ieksejas-kartibas-noteikumi [last viewed November 1, 2019]. 
"Since pre-trial detainees have not yet been convicted, it seems incomprehensible why they should be treated as if they have been", as well as the concern regarding the compliance of this treatment with the presumption of innocence ${ }^{6}$.

However, in this article, we aimed to focus on the second aspect, i.e., the prevalence of applying detention in practice and relevant problems, whereof the General Assembly of the Council of Europe, assessing the general situation in the CE Member States in 2015, has recognised that overuse of detention and application of it incompatibly with its legal purpose exist and are widespread.

What is the situation like in Latvia - is detention widely applied and what are the trends in its application? What are the problematic situations that the professionals, involved in the practical course of criminal proceedings, identify in the application of detention? Likewise, the question - does the fact per se that detention had been applied have or does not have an impact on the final outcome of criminal proceedings? These are the questions, answers to which were sought in this research, the outcomes of which are presented in this publication.

In the course of the research, foreign and international studies on the particular issue have been identified and reviewed, as well as supplemented with the accessible statistics on the Latvian situation, rulings by the Latvian courts, and also the data from surveying professionals practically involved in criminal proceedings.

It must be recognised that rulings- and statistics-based analysis in Latvia is significantly hindered due to several circumstances, mainly, inaccessibility of information for analysis and the fact that accessible sources as to their nature are not sufficiently informative. Hence, research is significantly hindered and, in some aspects, event made impossible by the absence of qualitative statistical data on several matters, for example, refusals to satisfy the request to apply detention and their rate, the number and proportion of persons, who had been detained previously and who have been sentenced to deprivation of liberty, in the total number of persons sentenced to deprivation of liberty ${ }^{7}$, "unconvincing" statistics with respect to the application of detention and its replacement by bail. Likewise, a significant, although objectively justified, an obstacle is the fact that rulings on applying detention are not publicly accessible. Research is also significantly hindered by the fact that, in Latvia, since mid-2017, the possibility has been envisaged that the final court's judgement may be also prepared in the so-called abbreviated form ${ }^{8}$, which often is useless for research purposes due to very small amount of information included in it (for example, often such judgements do not comprise the profile of the sentenced person, which prevents the researcher from assessing the appropriateness of the applied sanction, etc.).

6 Lippke R. L. Preventive Pre-trial Detention without Punishment. Res Publica, 20:111, 2014, p. 112 Available at: https://doi.org/10.1007/s11158-013-9234-6 [last viewed November 1, 2019].

7 This kind of statistical information is not available. Likewise, in the course of conducting the research, the absence of it was confirmed by persons responsible for statistical data in various areas (Information Centre of the Ministry of the Interior, the Court Administration, the Prison Administration).

8 See CPL Section 530. 
Notwithstanding the insufficient accessibility of statistical data and rulings useful for analysis, the research was not discontinued and attempts were made to identify the problematic situations by analysing the available information as well as by surveying practitioners. In the course of the research, 274 rulings of first instance court that had entered into force ${ }^{9}$ pertaining to six criminal offences, freely chosen, envisaged in the Criminal Law ${ }^{10}$ (hereafter - CL) were analysed. Those judgements that at the moment when the research was concluded, i.e., 30 September 2019, for the period from 1 October 2018 until 30 September 2019, were available in the database of anonymised rulings ${ }^{11}$ were analysed. The following data characterise the lawyers involved in the survey on the practical application of criminal procedure: the survey was conducted by using Google survey tool, 380 practitioners responded, among them - 121 advocates, 105 investigators, 87 prosecutors, 53 judges, and 10 investigative judges.

\section{Prevalence of applying detention}

Excessive application of detention (overuse and abuse of pre-trial detention) may be viewed in the context of overuse of the criminal justice system, which, validly, has been foregrounded as a problem in Europe ${ }^{12}$.

In the course of the research, the practitioners were also asked to give their opinion regarding the frequency of applying detention in Latvia. The responses revealed a lack of consensus in groups of various respondents, depending on the are a of their professional employment (by the way, this trend is also observed in responses to other questions in the questionnaire).

Respondents were given the opportunity to rate the application of detention in Latvia by choosing one of the following responses: 1) much too frequently; 2) more than it would be necessary, 3) in accordance with the need, 4) more rarely than it would be necessary, 5) much too rarely, or to provide another assessment.

The analysis of all responses shows that $38 \%$ of respondents recognise that detention is applied in accordance with the need, whereas the remaining point to inappropriate application, by applying either too frequently or too rarely. There are more of those who consider that detention in Latvia is applied too frequently, compared to ones who believe that detention should be applied more frequently (see Figure 1).

\footnotetext{
9 See the list of judgements in Bibliography section below.

10 Criminal Law. Available at: https://likumi.lv/ta/en/en/id/88966 [last viewed November 1, 2019].

11 See https://manas.tiesas.lv/eTiesasMvc/nolemumi [last viewed November 1, 2019].

12 See in greater detail the fundamental study of this issue - Overuse in Criminal Justice System. On Criminalization, Prosecution and Imprisonment. United Kingdom: Interesentia Ltd, 2019.
} 


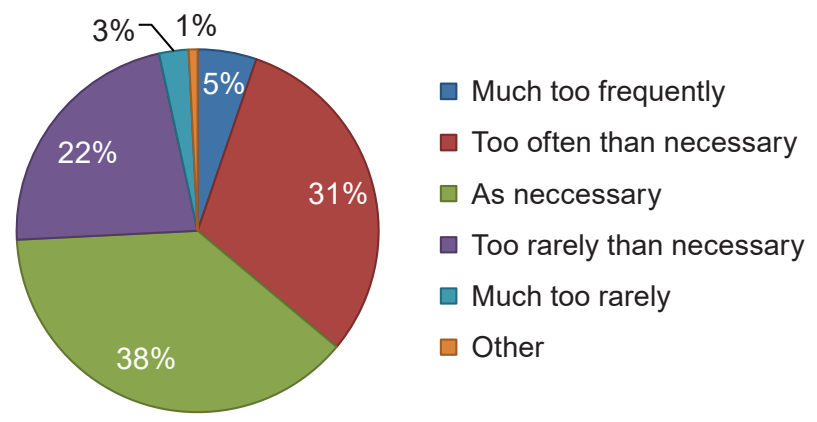

Figure 1. Prevalence of applying detention - All respondents

Assessments provided by various groups of respondents differ significantly (see Figures 2, 3, 4, 5, 6).

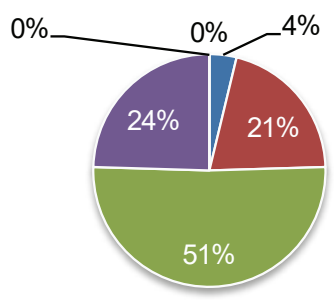

Figure 2. Prevalence of applying detention - Judges

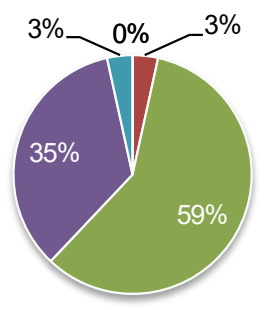

Figure 4. Prevalence of applying detention - Prosecutors

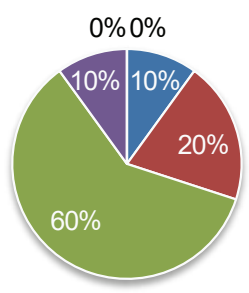

Figure 3. Prevalence of applying detention - Investigative judges

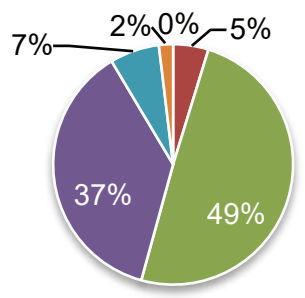

Figure 5. Prevalence of applying detention - Investigators

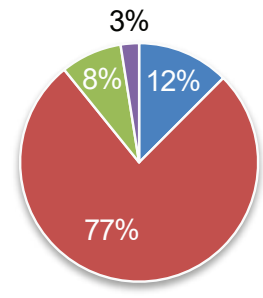

Figure 6. Prevalence of applying detention - Advocates 
We see that detention is perceived as being overused in Latvia in the majority of cases $(77 \%+12 \%)$ by advocates, i.e., the persons who are basically involved in providing defence, whereas $38 \%$ of prosecutors and $44 \%$ of investigators believe that detention is applied more rarely than it would be necessary or much too rarely. As regards judges (including investigative judges, whose competence includes the application of detention during the pre-trial proceedings), the majority of them (51\% and $60 \%$ ) are of the opinion that detention is applied in accordance with the need. At the same time, a sufficiently large number of judges see the application of detention contrary to the need - admitting both too rare and too frequent application thereof. Hence, it can be concluded that the respondents' assessment of the prevalence of applying detention is not homogenous and should be linked to different impressions related to affiliation with a certain criminal procedural "role".

The numbers revealing the dynamics of prison inmates (including those held in detention $)^{13}$ in Latvia, reveal a positive trend - in absolute numbers, there is a constant trend in decreasing prevalence of applying detention (see Figure 7). The same applies to changes in the total number of prison inmates - minors.

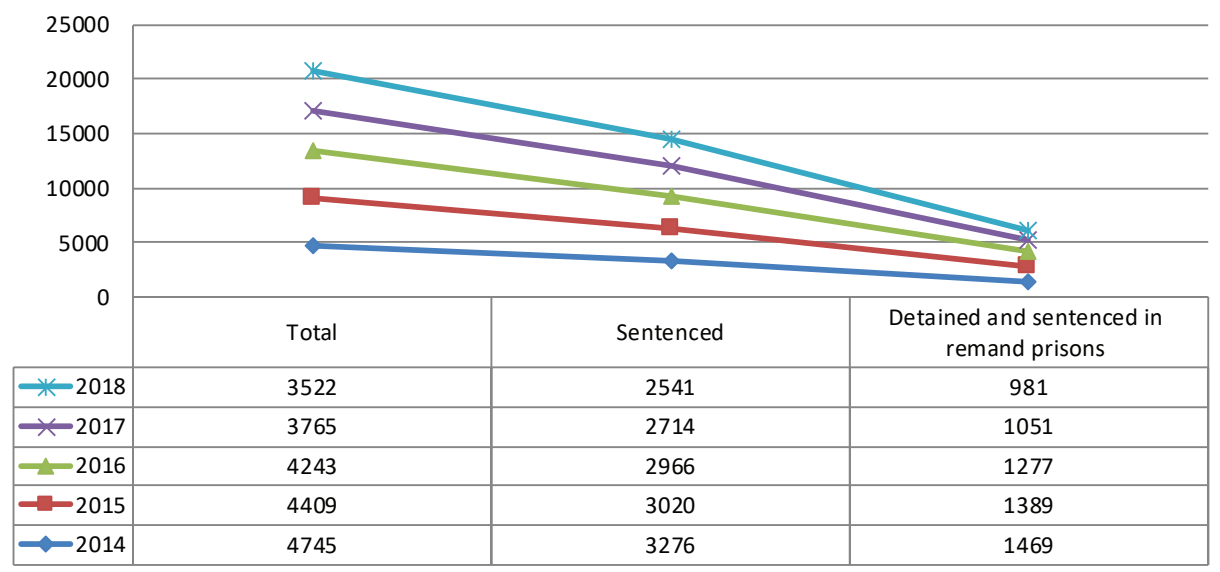

Figure 7. Dynamics in the number of prison inmates

Not very rapidly, yet the proportion of detained persons among prison inmates is also decreasing. Thus, in 2014 it was $31 \%$, whereas in $2018-28 \%$. However, it has to be noted that looking at the situation in the cross-section of decades, this trend is far from being unequivocal, because, interestingly, immediately after restoration of independence, i.e., on 01.01.1991, percentage-wise the proportion of detained persons among prison inmates in general was $28 \%$, whereas, for example,

13 See statistical data available on the homepage of the Prison Administration: Ieslodzijuma vietu pārvaldes publicējamā statistika 2018, and the homepage of the Central Statistical Bureau: https:// www.csb.gov.lv/lv/statistika/statistikas-temas/socialie-procesi/likumparkapumi/tabulas/skg090/ cietumos-esoso-personu-skaits-gada-beigas [last viewed November 1, 2019]. 
at the beginning of 2007 it was even $26 \% .{ }^{14}$ However, it must be noted that the total number of prison inmates was significantly higher.

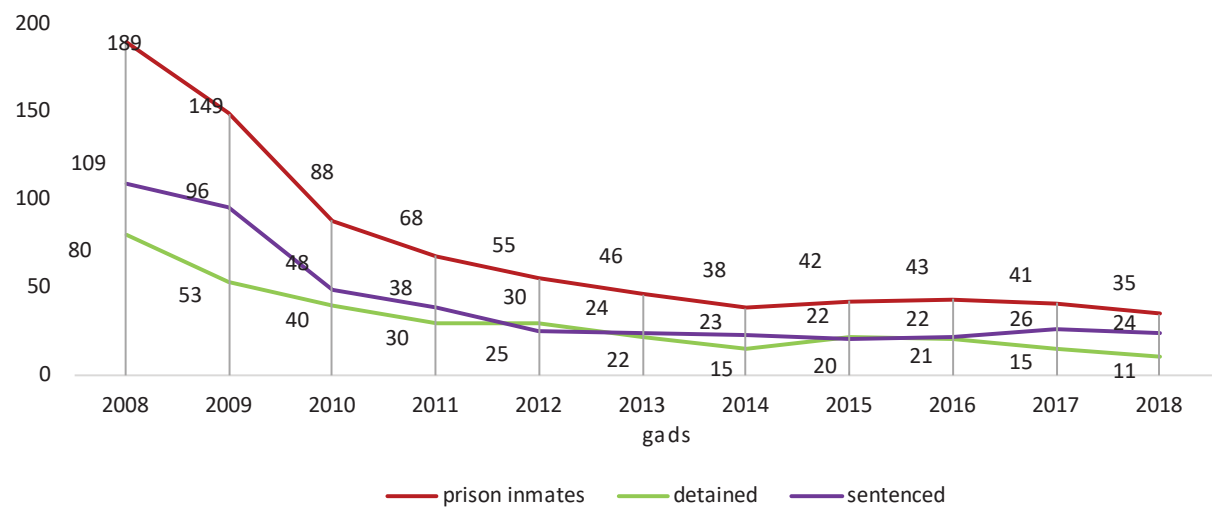

Figure 8. Changes in the number of minor prison inmates

In a project co-financed by the European Union and the Council of Europe, an effective tool for assessing detention has been developed ${ }^{15}$. It can be used to identify the most important statistical indicators and problematic situations in legal application, as well as to examine a particular country in a comparative context. The Council of Europe Annual Penal Statistics, better known as SPACE, occupies a significant place in using it.

Notwithstanding, in general, the significant progress made, in accordance with the Council of Europe Annual Penal Statistics with respect to applying detention (SPACE I) for the year $2018^{16}$, evaluation of Latvia is above the median and also above the average.

With respect to the proportion of prison inmates among population (number of prison inmates per 10000 inhabitants) (see Table 1).

Table 1

\begin{tabular}{|c|c|c|c|c|c|c|c|c|}
$\begin{array}{c}\text { Median } \\
\text { in } \\
\text { Europe }\end{array}$ & Latvia & Lithuania & Estonia & Germany & Finland & Poland & Russian & $\begin{array}{c}\text { Average } \\
\text { in } \\
\text { Europe }\end{array}$ \\
\hline 102.5 & 194.6 & 234.9 & 191.4 & 77.5 & 51.1 & 194.4 & 418.3 & 123.7 \\
\hline
\end{tabular}

14 Zahars V. Kriminālpolitika:mūsdienu tendencies un procesi. Daugavpils, Daugavpils universitātes Akadēmiskais apgāds, 2018, pp. 143-144.

15 Pre-trial detention assessment tool. Available at: https://rm.coe.int/pre-trial-detention-assessmenttool/168075ae06 [last viewed November 1, 2019].

16 Aebi M. F. \& Tiago M. M. SPACE I - 2018 - Council of Europe Annual Penal Statistics: Prison populations. Strasbourg: Council of Europe. 2018. Available at: http://wp.unil.ch/space/ files/2019/06/FinalReportSPACEI2018_190611-1.pdf [last viewed November 1, 2019]. 
Admittedly, with respect to the proportion of prison inmates among population, Latvia's indicators are presentable (see Table 2).

Table 2

\begin{tabular}{|c|c|c|c|c|c|c|c|}
\hline & Latvia & Lithuania & Estonia & Germany & Finland & Poland & Russia \\
\hline $\begin{array}{c}\text { Dynamics } \\
\text { 2014-2018, \% }\end{array}$ & -34.8 & -2.5 & -29.9 & -14.7 & -23.4 & -10.9 & -32.4 \\
\hline $\begin{array}{c}\text { Dynamics } \\
\mathbf{2 0 1 6 - 2 0 1 8 , \%}\end{array}$ & $-\mathbf{- 8 . 4}$ & -3.8 & -5.7 & -1.1 & -9.9 & 3.2 & No data \\
\hline
\end{tabular}

- With respect to the proportion of detained \% among prison inmates, see Table 3.

Table 3

\begin{tabular}{|c|c|c|c|c|c|c|c|c|}
\hline $\begin{array}{l}\text { Median } \\
\text { in } \\
\text { Europe }\end{array}$ & Latvia & Lithuania & Estonia & Germany & Finland & Poland & Russia & $\begin{array}{c}\text { Average } \\
\text { in } \\
\text { Europe }\end{array}$ \\
\hline 22.4 & 27.9 & 9.3 & 15.5 & 21.6 & 20.5 & 9.8 & No data & 26.0 \\
\hline
\end{tabular}

- With respect to mortality among prison inmates, see Table 4.

Table 4

\begin{tabular}{|c|c|c|c|c|c|c|c|c|c|}
\hline & $\begin{array}{l}\text { Median } \\
\text { in } \\
\text { Europe }\end{array}$ & Latvia & Lithuania & Estonia & Germany & Finland & Poland & Russia & $\begin{array}{c}\text { Average } \\
\text { in } \\
\text { Europe }\end{array}$ \\
\hline Total & 26.3 & 31.9 & 50 & 15.8 & 25.4 & 7.1 & 14.8 & 51 & 31 \\
\hline $\begin{array}{c}\text { Of } \\
\text { these, } \\
\text { suicides }\end{array}$ & 5.5 & 8 & 7.6 & 4 & 11.8 & 7.1 & 3 & 5.1 & 10.8 \\
\hline
\end{tabular}

Whereas an assessment below the European median for 2018 Latvia has received with respect to the following conditions:

- Costs per prison inmate (see Table 5).

Table 5

\begin{tabular}{|c|c|c|c|c|c|c|c|c|}
$\begin{array}{c}\text { Median } \\
\text { in } \\
\text { Europe }\end{array}$ & Latvia & Lithuania & Estonia & Germany & Finland & Poland & Russia & $\begin{array}{c}\text { Average } \\
\text { in } \\
\text { Europe }\end{array}$ \\
\hline 66.5 & 36.4 & 23.3 & 49.8 & 131.8 & 180.2 & 26.9 & 2.5 & 128 \\
\hline
\end{tabular}

- Proportion of foreigners among prison inmates.

Indeed, it must be admitted that the number of foreigners among prison inmates in Latvia is pronouncedly low (see Figure $9^{17}$ ), hence, actually, there are no current problems linked to this condition.

Statistical data available on the homepage of the Prison Administration: Ieslodzijuma vietu pārvaldes publicējamā statistika 2018 [last viewed November 1, 2019]. 


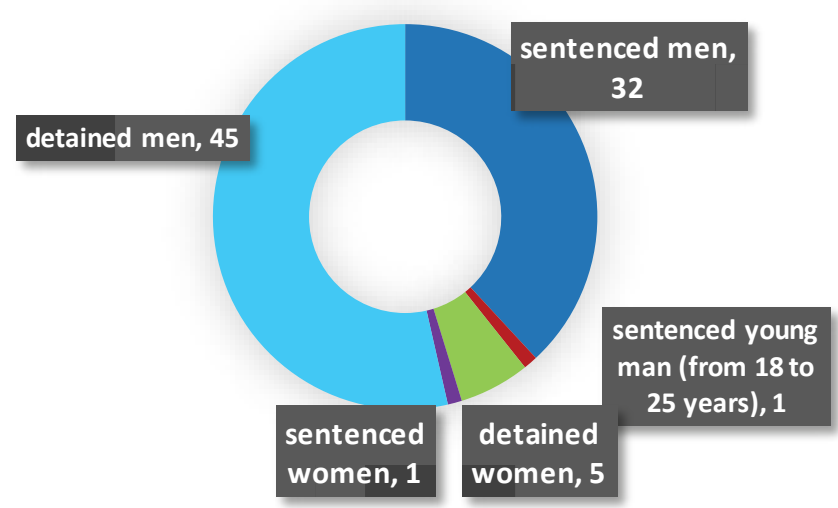

Figure 9. Number of foreign prison inmates at the end of 2018

Unfortunately, it must be admitted, that it is impossible to assess the average length of detention, reoccurrence and other data in Latvia, since the respective statistics do not exist.

Summing up the outcome of research thus far regarding prevalence of detention in Latvia, the following conclusions can be made:

$\gg$ Due to shortage of statistics, several parameters cannot be assessed, for example.

- Application of detention and refusal to apply detention;

- Average length of detention;

- The number of detained persons in the total number of persons who have the right to defence;

» To a large extent, the subjective attitude towards the application of detention is determined by the affiliation with a certain are a of professional activities;

> There is a decreasing trend in the application of detention;

» There is a decreasing trend in the proportion of detained persons among prison inmates;

» Many statistical indicators in Latvia are still above the median and also above the average indicator in Europe, which leaves room for improving the application of detention in practice.

Undeniably, since 2015, when the General Assembly of the Council of Europe adopted the resolution, the situation in Latvia has considerably improved; however, the country still remains in the group of CE countries, where frequent application of detention is observed, and this leads to the recognition that improvements are still required, inter alia, possibly, those that GA of CE at the time included in its recommendation, specifically: 
» implement measures aimed at reducing pre-trial detention, including the following:

- raising awareness among judges and prosecutors of the legal limits placed on pre-trial detention by national law and the European Convention on Human Rights and of the negative consequences of pretrial detention on detainees, their families and on society as a whole;

- ensuring that decisions on pre-trial detention are taken by more senior judges or by collegiate courts and that judges do not suffer negative consequences for refusing pre-trial detention in accordance with the law;

- ensuring greater equality of arms between the prosecution and the defence, including by allowing defence lawyers unfettered access to detainees, by granting them access to the investigation file ahead of the decision imposing or prolonging pre-trial detention, and by providing sufficient funding for legal aid, including for proceedings related to pre-trial detention;

take appropriate measures to prevent "forum shopping" by prosecutors;

refrain from using pre-trial detention for purposes other than the administration of justice and to release all detainees currently held for any abusive purposes or under any abusive procedure

\section{Problem situations in practice of applying detention}

In research, the current problematic issues in applying detention were identified by finding out the opinion of lawyers involved in the practical application of criminal procedure - i.e., a survey. They were asked to provide their opinion on how prevalent (always / quite frequently / frequently / rarely / very rarely / never) the following situations were:

» Insufficiently substantiated proposals to apply detention;

» Insufficiently substantiated decisions on applying detention;

$\gg$ Too strict (and / or unfeasible in practice) legal requirements with respect to the application of detention;

> Application of detention that is inappropriate for the actual situation (detention applied without need);

» Refusals to apply detention that are inappropriate for the actual situation (detention is not applied, although it was necessary);

» Materials that substantiate detention are not shown to the defence providers.

The assessment of survey outcomes allows to conclude that advocates are the subgroup of respondents that holds the most critical views, whereas the investigative judges are the least critical. Respondents held radically different opinions regarding some positions, depending on the particular group they 
belonged to. All groups of respondents, except investigators, saw insufficiently substantiated proposals to apply detention as the most prevalent situation from the entire list. According to the lawyers, almost as prevalent was the failure to show the investigation file to defence providers. All the groups of respondents indicated that the least prevalent was inapplication of detention or inappropriate application with regard to the actual situation (this opinion was not shared by advocates).

Turning to a slightly more detailed assessment of some problem situations, almost all the groups of respondents noted the prevalence of insufficient substantiation of the proposal to apply detention (i.e., a procedural document whereby, in Latvia, during the pre-trial proceedings, the official in charge of the proceedings proposes to the investigative judge to apply detention to a particular person). Graphical presentation of the summary of opinions is provided in Figure 10 below, showing the variants of responses in \% amongst all the responses in the respective subgroups of respondents.

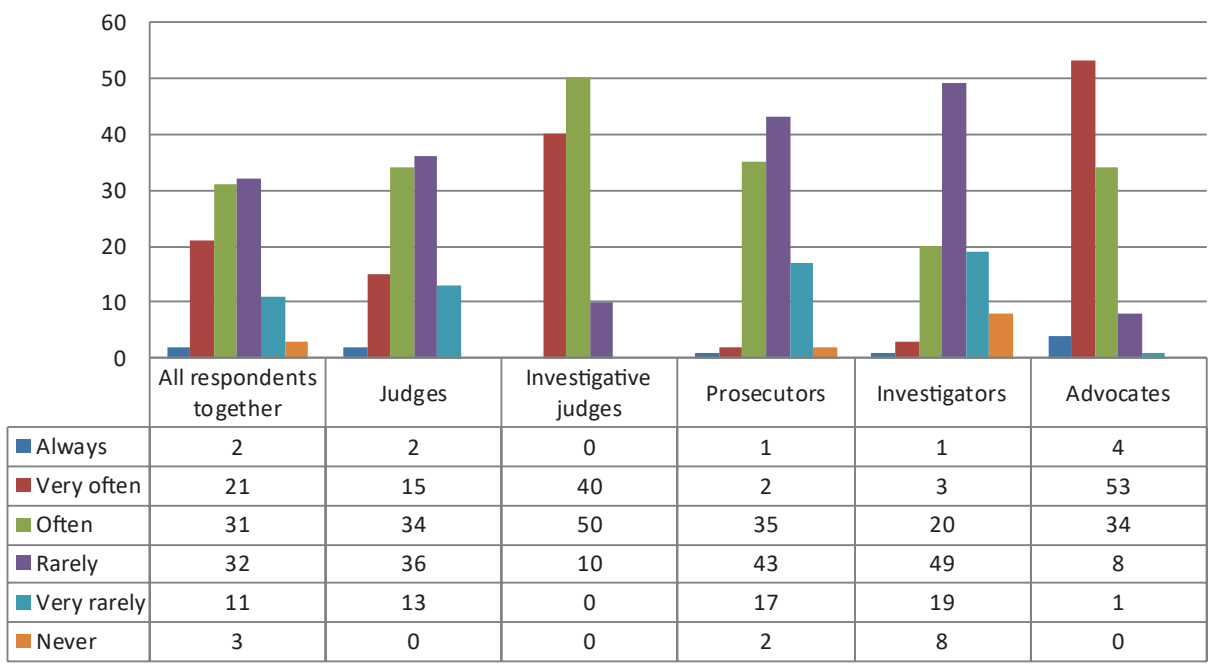

Figure 10. Insufficiently substantiated proposals to apply detention (\% break-down of respondents' answers)

$54 \%$ of respondents assess this problem as prevailing often, very often or always; this opinion was shared by $51 \%$ of all judges, $90 \%$ of investigative judges, whose daily duties include review of such proposals, $38 \%$ of prosecutors, $24 \%$ of investigators (whose duties most often include preparing such proposals) and $91 \%$ of advocates.

Comparatively, judges' decisions on applying detention are assessed much more positively because the prevalence of insufficiently substantiated decisions is assessed as significantly less common in all groups of respondents. Actually, only the majority of advocates assess it as a phenomenon that is observed often, very often or always, whereas in the other four groups of respondents it is assessed, with convincing majority $\%$ of voices, as being seen rarely, very rarely or never (see Figure 11). 


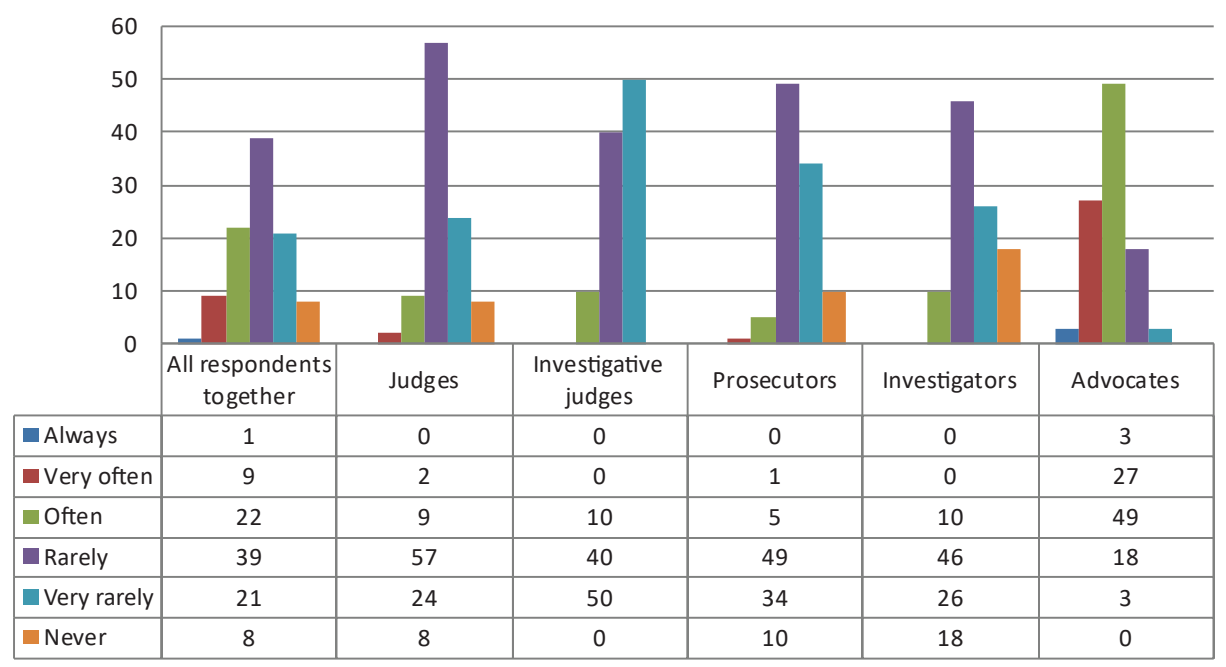

Figure 11. Insufficiently substantiated decisions on applying detention (\% break-down of respondents' answers)

Excessive strictness of legal and practical requirements regarding proposals/ decisions on applying detention was assessed as rarely, very rarely or never prevalent by all groups of respondents. Likewise, application of/refusal of detention inappropriate for the actual situation was assessed in all groups of respondents as rarely, very rarely or never prevalent, except advocates, who did not uphold the others' view regarding the inappropriate application of detention (the majority believe that it is encountered often or very frequently).

The last problem that the respondents were requested to assess is vividly outlined in the judgement by ECHR, unfavourable for Latvia, in case Mikelsons v. Latvia ${ }^{18}$, i.e., the failure to show to defence providers the investigation file, by which application of detention is substantiated. It is not surprising that it is still perceived as a very topical problem by advocates, of which $79 \%$ indicate that this problem is encountered often, very often or always. However, the answers provided by other groups of respondents attract interest. Thus, for example, investigative judges, whose direct job duties include the application of detention, also admit that this problem exists. However, the respondents from this group see the prevalence of this problem as rare or very rare (see Figure 12). At the same time, almost one-fifth of investigators, who, in the majority of cases, would have to ensure that the appropriate file materials are shown, indicate that the problem of not showing the investigation file is never encountered.

18 ECHR judgment of 3 November 2015 in case Mikselsons v. Latvia (Application No. 46413/10). Available at: http://hudoc.echr.coe.int/eng?i=001-158350 [last viewed November 1, 2019]. 


\begin{tabular}{|c|c|c|c|c|c|c|}
\hline 50 & & & & & & \\
\hline 45 & & & & & & \\
\hline $\begin{array}{l}40 \\
35\end{array}$ & & & & & & \\
\hline 30 & & & & & & \\
\hline 25 & & & & & - & \\
\hline 20 & & & & & 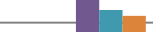 & \\
\hline 15 & & & & & & \\
\hline 10 & & & & & & \\
\hline 5 & & & & & & 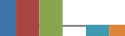 \\
\hline 0 & & & & & & \\
\hline & $\begin{array}{c}\text { All respondents } \\
\text { together }\end{array}$ & Judges & $\begin{array}{c}\text { Investigative } \\
\text { judges }\end{array}$ & Prosecutors & Investigators & Advocates \\
\hline Always & 18 & 0 & 10 & 2 & 9 & 46 \\
\hline Very often & 13 & 8 & 10 & 5 & 9 & 27 \\
\hline Often & 14 & 26 & 30 & 7 & 11 & 14 \\
\hline Rarely & 19 & 15 & 20 & 33 & 28 & 3 \\
\hline Very rarely & 15 & 28 & 0 & 14 & 22 & 5 \\
\hline Never & 21 & 23 & 30 & 39 & 21 & 5 \\
\hline
\end{tabular}

Figure 12. Not showing the materials of the investigation file, which substantiate application of detention, to defence providers (\% breakdown of respondents' answers)

Summing up the outcome of survey, it can be concluded that the assessment of potentially possible problem situations among the respondents radically differed depending on the group of their professional affiliation, which, to a certain extent, proved the inability to distance oneself from one's own role in criminal proceedings and to provide an impartial assessment even in a situation, where opinions are expressed anonymously. In some measure, this can be explained because professionals associate particular problem situations with difficulties in performing obligations entrusted to them.

\section{The impact of applied detention on outcome of criminal proceedings}

A categorical assessment has been expressed in literature: it is hard to see pretrial detention as anything other than pre-punishment - that is, as a preliminary for the real or further punishment of the accused that is believed to be more or less inevitable ${ }^{19}$. At this point, abstaining from strictly subscribing to opinion this categorical, the views expressed in literature can be supported, i.e., that the fact of applying detention may have an impact on the outcome of criminal proceedings. This can be manifested in various ways, for example, in the fact that a detained person in reality has more limited access to legal assistance or that his or her possibilities

19 Lippke R. L. Preventive Pre-trial Detention without Punishment. Res Publica, 20:111, 2014, pp. 113-114; Available at: https://doi.org/10.1007/s11158-013-9234-6 [last viewed November 1, 2019]. 
to prepare for defence are, actually, restricted ${ }^{20}$. Likewise, that detained persons are more inclined to reach a plea agreement, based on the already mentioned decreased possibilities of legal assistance, as well as the wish for certainty ${ }^{21}$. Arguably, in the Latvian legal situation, which differs significantly from the US or Canada, not all these lines of influence will be equally important, however, undeniably, the detention of a person restricts his or her actual possibility to exercise his or her rights compared to a person who has not been detained. The authors will refrain from assessing how typical it is for Latvia, because that would require a more extensive research that, inter alia, requires existence of statistical data, access to relevant documents and persons.

The circumstance, which we have included in this study, is the relation between the fact of detention with the "measurable" final outcome of criminal proceedings i.e., conviction or exoneration of a person and the type and scope sanction applied to the convicted person. Studies conducted in the USA show that detention has an independent impact on conviction/exoneration/type of punishment and the length of prison sentence ${ }^{22}$. The same findings can be found in literature about Canada ${ }^{23}$, Russia $^{24}$. The impact of the fact that detention had been applied on the sentence has not been studied in Latvia. Objective grounds can be found for this, which have hindered analysis and drawing of conclusions also while conducting the current study, i.e., there was a lack of information to analyse. In Latvia, it is very difficult to conduct

20 See, for example, Sacks M. \& Ackerman A. R. Bail and Sentencing: Does Pretrial Detention Lead to Harsher Punishment? Criminal Justice Policy Review, 25(1), 2014. p. 62. Available at: https:// doi.org/10.1177/0887403412461501 [last viewed November 1, 2019]; Lee J. G. To Detain or Not to Detain? Using Propensity Scores to Examine the Relationship Between Pretrial Detention and Conviction. Criminal Justice Policy Review, 30(1), 2019, pp. 128-152. Available at: https://doi. org/10.1177/0887403416668016 [last viewed November 1, 2019].

21 Euvrard E., Leclerc C. Pre-trial detention and guilty pleas: Inducement or coercion? Punishment \& Society, 2017, 19(5), pp. 525-542. Available at: https://doi.org/10.1177/1462474516670153 [last viewed November 1, 2019]; Lee J. G. To Detain or Not to Detain? Using Propensity Scores to Examine the Relationship Between Pretrial Detention and Conviction. Criminal Justice Policy Review, 30(1), 2019, pp. 128-152. Available at: https://doi.org/10.1177/0887403416668016 [last viewed November 1, 2019]; Petersen N. Do Detainees Plead Guilty Faster? A Survival Analysis of Pretrial Detention and the Timing of Guilty Pleas. Criminal Justice Policy Review, 2019, pp. 1-21. Available at: https://doi.org/10.1177/0887403419838020 [last viewed November 1, 2019].

22 Sacks M. \& Ackerman A. R. Bail and Sentencing: Does Pretrial Detention Lead to Harsher Punishment? Criminal Justice Policy Review, 25(1), 2014, p. 62. Available at: https:// doi.org/10.1177/0887403412461501 [last viewed November 1, 2019]; Lee J. G. To Detain or Not to Detain? Using Propensity Scores to Examine the Relationship Between Pretrial Detention and Conviction. Criminal Justice Policy Review, 30(1), 2019, pp. 128-152. Available at: https:// doi.org/10.1177/0887403416668016 [last viewed November 1, 2019]; Dobbie W., Goldin J., Yang C. The Effects of Pre-Trial Detention on Conviction, Future Crime, and Employment: Evidence from Randomly Assigned Judges. The American Economic Review, Vol. 108(2), 2018, pp. 201-240. Available at: https://pubs.aeaweb.org/doi/pdf/10.1257/aer.20161503 [last viewed November 1, 2019].

23 Euvrard E., Leclerc C. Pre-trial detention and guilty pleas: Inducement or coercion? Punishment \& Society, 19(5), 2017, p. 538. Available at: https://doi.org/10.1177/1462474516670153 [last viewed November 1, 2019].

24 Titaev K. D. Pretrial detention in Russian criminal courts: a statistical analysis. International Journal of Comparative and Applied Criminal Justice, 41: 3, 2017, pp. 145-161, Available at: 10.1080/01924036.2016.1239117 [last viewed November 1, 2019]. 
an objective, numbers-based research because frequently statistical data are nonexistent, for example, there are no statistics on how many sentenced prison inmates had been or had not been detained previously. Obviously, this is one of the issues that require in-depth research, with ensured access to comprehensive information about individual persons who are in prisons, which exceeds the boundaries of this study.

In the framework of this research, to identify the situation, the publicly accessible information and information provided by the Prosecutor's Office of the Republic of Latvia about rehabilitated persons was analysed, practitioners' observations were collected, and a selection of court judgements was analysed.

The first aspect - the impact of detention on the adjudication of the matter in its merits - exoneration or finding a person to be guilty. The respondents in the survey were asked the question: Can you, on the basis of your professional observations, uphold the statement that, if a person had been detained, the possibility to be exonerated is lower compared to the case when the person had not been detained. The results are summarised in Figure 13.

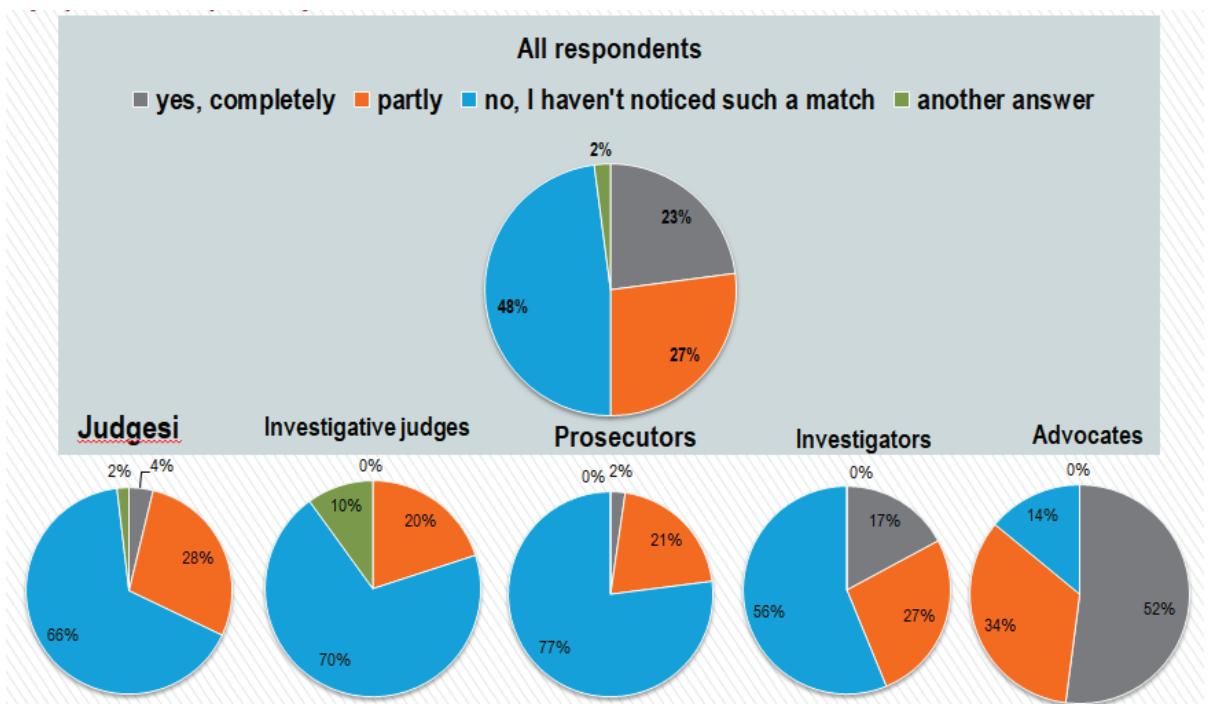

Figure 13

As shown, the respondents' opinions differ significantly, depending on their "criminal procedural role". The connection between the application of detention and decreased possibilities to be fully or partially exonerated has been observed by the majority of advocates, whereas the representatives of all other groups of respondents, in the majority of cases, have not discerned this coincidence in their 
professional life. The available statistical information on rehabilitated persons ${ }^{25}$ during criminal prosecution and adjudication ${ }^{26}$ in $2015-2018$ is shown in Table 6.

Table 6

\begin{tabular}{|l|c|c|c|c|}
\hline & 2015 & 2016 & 2017 & 2018 \\
\hline $\begin{array}{l}\text { Exonerated persons and those, against whom } \\
\text { proceedings were terminated on rehabilitative }\end{array}$ & $\mathbf{3 3 9}$ & $\mathbf{3 0 1}$ & $\mathbf{3 0 0}$ & $\mathbf{2 7 2}$ \\
\begin{tabular}{|} 
grounds, total \\
including those, to whom detention was applied \\
during the proceedings
\end{tabular} & $\mathbf{8}$ & $\mathbf{4}$ & $\mathbf{6}$ & $\mathbf{1 6}$ \\
\hline $\begin{array}{l}\text { including persons, who were exonerated or } \\
\text { the proceedings against whom were terminated } \\
\text { on rehabilitative grounds in court }\end{array}$ & $\mathbf{1 0 4}$ & $\mathbf{1 0 2}$ & $\mathbf{1 3 4}$ & $\mathbf{9 1}$ \\
\hline $\begin{array}{l}\text { including those, to whom detention was applied } \\
\text { during the proceedings }\end{array}$ & $\mathbf{6}$ & $\mathbf{4}$ & $\mathbf{6}$ & $\mathbf{9}$ \\
\hline $\begin{array}{l}\text { including persons, the proceedings against } \\
\text { whom were terminated on rehabilitative } \\
\text { grounds during the pre-trial proceedings }\end{array}$ & $\mathbf{2 3 5}$ & $\mathbf{1 9 9}$ & $\mathbf{1 6 6}$ & $\mathbf{1 8 1}$ \\
\hline $\begin{array}{l}\text { including those, to whom detention was applied } \\
\text { during the proceedings }\end{array}$ & $\mathbf{2}$ & $\mathbf{0}$ & $\mathbf{0}$ & $\mathbf{7}$ \\
\hline
\end{tabular}

As shown above, the number of exonerated persons during criminal prosecution and trial has decreased. At the same time, it must be admitted that, since 2016, the number of cases received for starting criminal prosecution has likewise decreased, and since 2015 - also the number of persons transferred to courts ${ }^{27}$. However, in percentage, the decrease in exonerated persons is many times more significant than the decrease in other statistical indicators. Thus, for instance, the number of persons transferred to a court, comparing 2018 and 2017, has decreased by $2.7 \%$, whereas the number of rehabilitated persons - by $32.1 \%$. In 2018, the number of those rehabilitated persons, who had been detained during the proceedings, significantly increased.

In Latvia, information on the number or \% of all the persons, to whom security measures can be applied and who had been detained, is not publicly accessible; hence, it is impossible to determine exactly, whether those, to whom detention had been applied, are exonerated as often / less often / more often compared to those who had not been detained. Very approximate calculations (taking into account the total number of

25 Statistical information on the performance outcomes of the Prosecutor's Office of the Republic of Latvia in 2018. Available at: http://www.prokuratura.gov.lv/lv/noderigi/gada-parskati [last viewed November 1, 2019], and information prepared by the Prosecutor's General Office upon the researchers' request - unpublished material.

26 Statistical data on persons who have been rehabilitated during the pre-trial proceedings is not publicly available.

27 Statistical information on the performance outcomes of the Prosecutor's Office of the Republic of Latvia in 2018. Available at: http://www.prokuratura.gov.lv/lv/noderigi/gada-parskati [last viewed November 1, 2019]. 
persons, to whom in the respective year the status of a person with the right to defence has been applied ${ }^{28}$ and the number of persons in remand prison) allow to conclude that detention had been applied to less than $8 \%$ of the persons ${ }^{29}$, who had the right to defence. The proportion of detained persons in the total number of rehabilitated accused persons is, as follows: in $2018-17.6 \%$, in $2017-4.4 \%$, in $2016-3.9 \%$, in $2015-7.8 \%$, in $2014-2.5 \%$. Thus, the hypothesis can be advanced (although, to prove it, more precise statistical data and in-depth analysis thereof would be required) that percentage-wise, in recent years, fewer of those to whom detention was applied were rehabilitated, compared to those who had not been detained. At the same time, the statistics of 2018 proved that also the fact that a person had been detained had not hindered rehabilitating a significant proportion of persons.

Although also in literature, with respect to other countries, conjectures have been made regarding the reasons why a relatively small number of those who are detained are exonerated (rehabilitated) ${ }^{30}$, also, in personal conversations with parties involved in criminal proceedings, opinions have been expressed that judges tend to convict more of those who are detained. However, our personal observations, as well as the statistical data, rather supports the opinion that the detention does not have an arbitrary or unlawful impact on exoneration. I.e., judges tend to convict more often those who are detained not simply because a person is detained and, for example, in the case of exoneration, the State would have to pay compensation, but due to fact that already at the moment of applying detention, the validity of the initial suspicion regarding a committed criminal offence is sufficiently strictly examined. Therefore, we would venture a hypothesis that requires further verification that in such an important matter as recognising a person as guilty or not, the fact of applied detention per se is not decisive.

Another intuitive approach, which was confirmed in the course of the research, developed with respect to determining the type of punishment and sanction for persons recognised as being guilty, which is the next issue to be examined.

The respondents of the survey were asked three questions regarding their professional observations on how the fact of detention influenced the type of punishment and sanction.

The first question: Can you, on the basis of your professional observations, support the statement that in the conditions where a person had been detained, the possibility to be sentenced to a punishment that is not related to deprivation of liberty is lower than in case where a person had not been detained? The summary of responses is presented in Figure 14.

28 Statistics on persons with the right to defence, the Information Centre of the Ministry for the Interior. Available at: https://www.ic.iem.gov.lv/lv/node/769 [last viewed November 1, 2019].

29 However, this indicator should be viewed as rather vague and unspecific, since security measures, inter alia, detention, can be applied to only part of persons enjoying the right to defence. Likewise, this statistical report does not include persons, with respect to whom the proceedings have been terminated because the existence of a criminal offence or elements of it had not been confirmed.

30 See, for example, Titaev K. D. Pretrial detention in Russian criminal courts: a statistical analysis. International Journal of Comparative and Applied Criminal Justice, 41: 3, 2017, pp. 145-161. Available at: 10.1080/01924036.2016.1239117 [last viewed November 1, 2019]. 


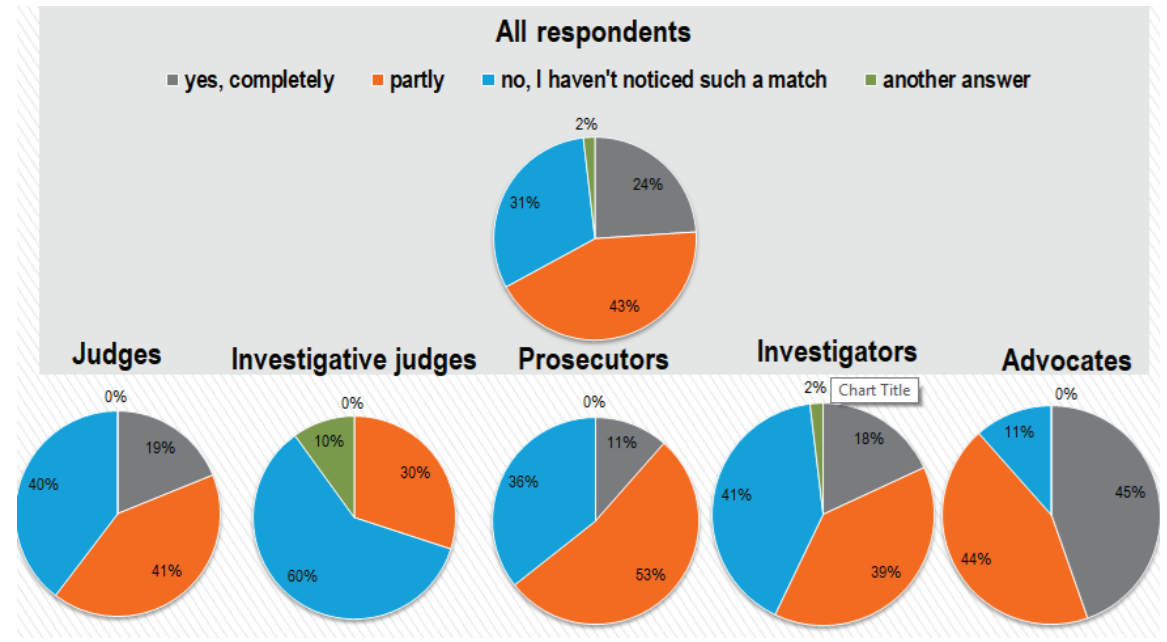

Figure 14

Again, we see that the answers differ depending on the group of respondents. However, the majority of respondents in all the groups, except investigative judges (in accordance with the Latvian legal regulation, these are the judges who do not examine criminal cases on their merits and do not convict), can fully or partially agree that the fact of detention decreases the possibility for a person to be sentenced to a punishment that is not related to deprivation of liberty.

The second question approached the issue from the opposite side, i.e., - Can you, on the basis of your professional observations, support the statement that in circumstances, where a person had been detained, the possibility to receive a prison sentence is higher compared to a situation, where detention had not been applied? The summary of responses is presented in Figure 15.

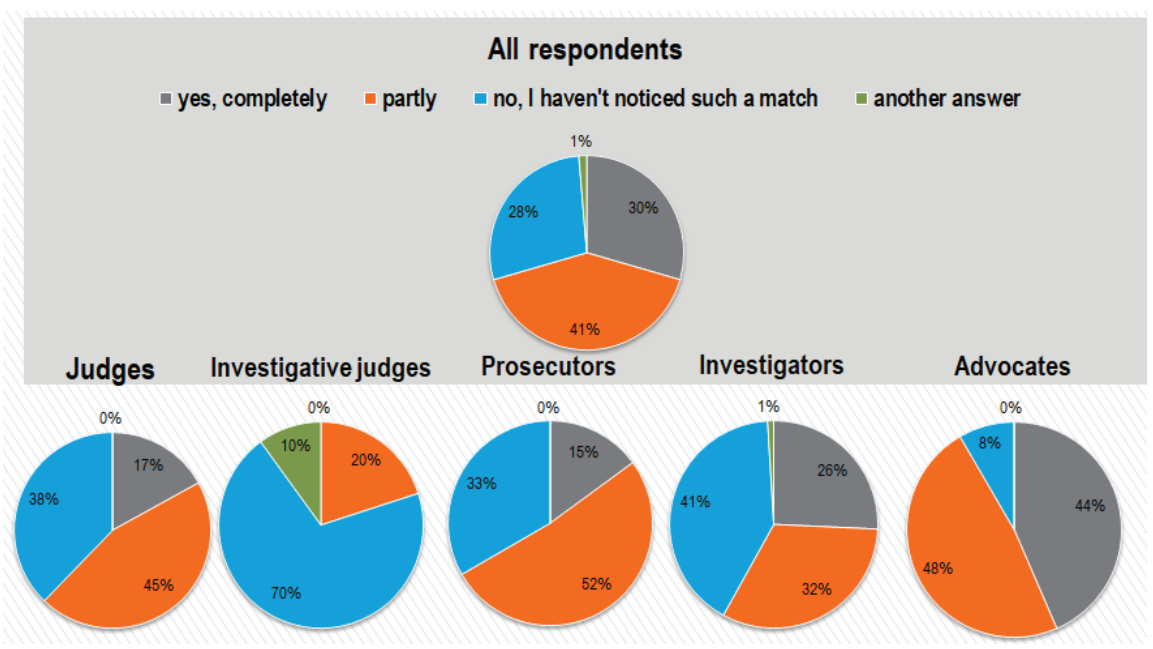

Figure 15 
We see that, although the answers should completely correspond to the ones given to the previous question, there are slight differences. Nevertheless, it can be recognised that the majority of respondents (except the investigative judges) admit that their professional observations confirm, in full or partially, the assumption that the type of sanction depends on whether the person has been/has not been detained.

And, finally, the third question, to which the respondents have answered with a surprising consensus - Can you, on the basis of your professional observations, support the statement that upon sentencing to deprivation of liberty a person, who had previously been detained in criminal proceedings, usually the term is not shorter than the period spent in detention? The summary of responses is presented in Figure 16 below.

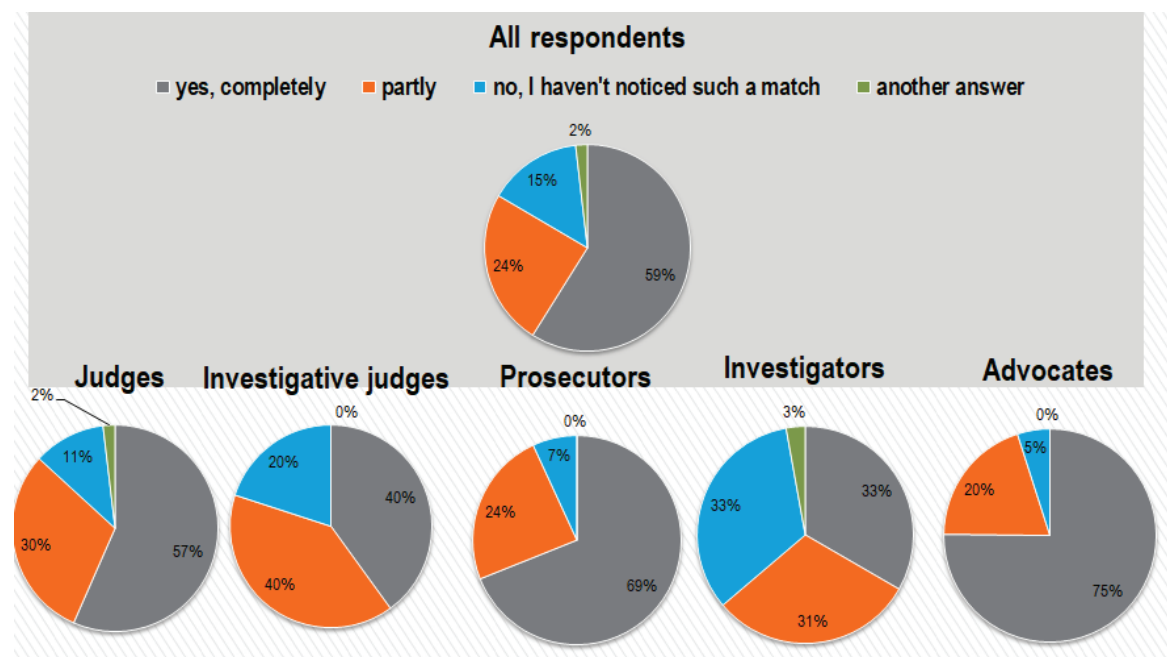

Figure 16

Clearly, in this case all the groups of respondents completely or partially supported the statement that, if a person had been detained in the course of criminal proceedings and later a sanction related to deprivation of liberty was applied then the duration of it, indeed, usually was not shorter than the time spent in detention. This assumption is further confirmed by the analysis of court rulings, conducted as part of the current research.

As regards other aspects of the impact of detention on the type of punishment and sanction, our analysis of court rulings leads to the following conclusions.

As noted above, the court rulings of the first instance courts from the database of anonymised court rulings (covering the period from 01.10.2018 to 30.10.2019) were analysed, these pertained to 274 persons, who had been charged with committing six types of criminal offences specified in CL.

The first type of offence - CL Section 116 Murder - the applicable punishment is deprivation of liberty for life or deprivation of liberty for the period from five to twenty years and probationary supervision for the term of three years. 
At the time of conducting the research, the database contained rulings with respect to 6 persons ${ }^{31}$. During the proceedings, five of them had been detained, while one person had not. However, they all had been sentenced to deprivation of liberty. Thus, the conclusion is that irrespectively of whether detention had been applied or not, they were convicted to actual deprivation of liberty.

The second type of offence to be researched were court rulings regarding persons, who had been charged with the offence envisaged in CL Section 125 (3), i.e., intentionally inflicting serious bodily injuries, which, due to the offender's negligence, caused the victim's death, or for intentionally inflicting grave bodily injuries, if this had been committed by an organised group. The applicable punishment is deprivation of liberty for the period from three to fifteen years, with or without confiscation of property, with probationary supervision for a period up to three years or without probation.

Rulings pertaining to 19 persons were examined ${ }^{32}$ and the acquired information is presented in Table 7.

Table 7

\begin{tabular}{|r|c|}
\hline \multicolumn{1}{|l|}{ Total } & Number \\
\hline \multicolumn{1}{|l|}{ Detention had been applied } & 19 \\
\hline \multicolumn{1}{|r|}{ Sentenced to DL } & 8 \\
\hline Sentenced to conditional DL & 3 \\
\hline Another sanction applied & - \\
\hline Setention had not been applied & 8 \\
\hline Sentenced to conditional DL & 3 \\
\hline Another sanction applied & - \\
\hline
\end{tabular}

As clearly seen in Figure 17, notwithstanding the grave consequences that have set in as the result of the criminal offence, the severity of expected punishment and deprivation of liberty as the only possible punishment envisaged in the sanction,

31 Available at: https://manas.tiesas.lv/eTiesasMvc/eclinolemumi/ECLI:LV:RVPT:2018:1026.11087 034718.2.S [last viewed November 1, 2019].

Rulings by district/municipal courts in criminal cases against persons charged with committing of the crime envisaged in CL Section 116. Available at: https://manas.tiesas.lv/eTiesasMvc/eclinolemumi [last viewed November 1, 2019]. Information about ECLI numbers of these cases can be found in the list "Legal practice: national" at the end of the article.

32 Rulings by district/municipal courts in criminal cases against persons charged with committing of the crime envisaged in CL Section 125 (3), which can be found on the site https://manas.tiesas.lv/ eTiesasMvc/eclinolemumi [last viewed November 1, 2019].Information about ECLI numbers of these cases can be found in the list "Legal practice: national" at the end of the article. 
deprivation is not always applied. Statistically, the possibility of conditional sentencing slightly increases, if the person has not been detained.
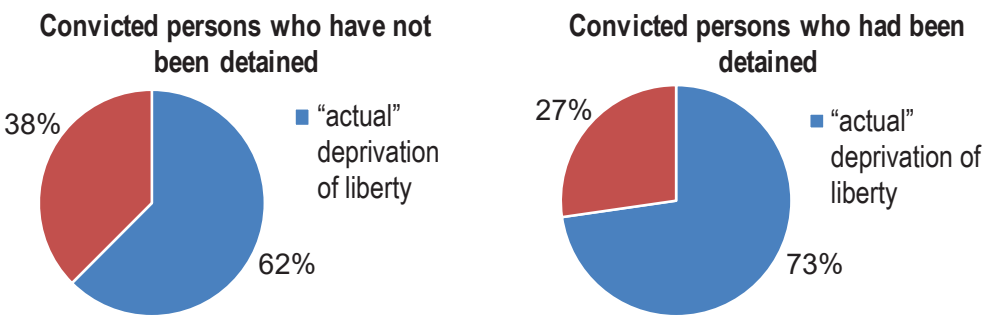

Figure 17

The third type of offence - CL Section 177 (1), which sets liability for acquiring property of another or the right to such property by abusing trust or by deceit (fraud), determining the punishment - deprivation of liberty for a period up to three years or temporary deprivation of liberty, or community work, or monetary fine. Rulings regarding 28 persons were analysed ${ }^{33}$ and the information is included in Table 8.

Table 8

\begin{tabular}{|c|c|}
\hline & Number \\
\hline Total & 28 \\
\hline Detention had been applied & 6 \\
\hline Sentenced to DL & 3 \\
\hline Sentenced to conditional DL & 1 \\
\hline Another sanction applied & 2 \\
\hline Detention had not been applied & 22 \\
\hline Sentenced to DL & 4 \\
\hline Sentenced to conditional DL & 7 \\
\hline Another sanction applied & 11 \\
\hline
\end{tabular}

As Figure 18 clearly shows, not being detained significantly increases the possibility of a sanction that is not linked to deprivation of liberty and conditional deprivation of liberty. Simultaneously, it should be taken into account that the incriminated crime is a less serious crime, the sanction of which comprises alternative punishments.

33 Rulings by district/municipal courts in criminal cases against persons charged with committing of the crime envisaged in CL Section 177 (1), which can be found on the site https://manas.tiesas.lv/ eTiesasMvc/eclinolemumi [last viewed November 1, 2019]. Information about ECLI numbers of these cases can be found in the list "Legal practice: national" at the end of the article. 

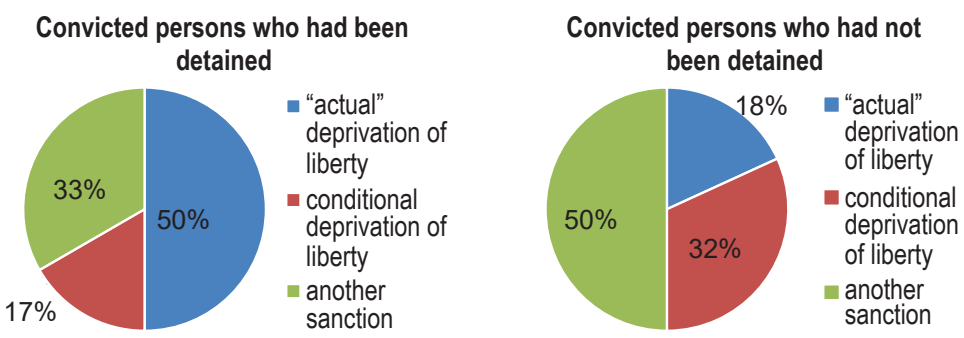

Figure 18

The fourth type of offence in accordance with CL Section 253 (1), i.e., unauthorised manufacture, acquisition, storage, transportation or forwarding of narcotic or psychotropic substances without the purpose of disposal of such substances had the largest number of available rulings. This was analysed with respect to persons, who had been convicted, and the applicable punishment for this offence is deprivation of liberty for the period up to three years or temporary deprivation of liberty, or community work, or a fine and probationary supervision for the period up to three years.

Rulings pertaining to sanctioning of 180 persons were examined ${ }^{34}$. The information obtained is presented in Table 9

Table 9

\begin{tabular}{|c|c|}
\hline & Number \\
\hline Total & 180 \\
\hline Detention had been applied & 34 \\
\hline Sentenced to DL & 32 \\
\hline Sentenced to conditional DL & 1 \\
\hline Another sanction applied & 1 \\
\hline Detention had not been applied & 146 \\
\hline Sentenced to DL & 36 \\
\hline Sentenced to conditional DL & 13 \\
\hline Another sanction applied & 97 \\
\hline
\end{tabular}

34 Rulings by district/municipal courts in criminal cases against persons charged with committing of the crime envisaged in CL Section 253 (1), which can be found on the site https://manas.tiesas.lv/ eTiesasMvc/eclinolemumi [last viewed November 1, 2019]. Information about ECLI numbers of these cases can be found in the list pratice at the end of the article. 
As clearly seen in Figure 19 below, not being already detained significantly increases the possibility of receiving a punishment that is not linked to deprivation of liberty and conditional deprivation of liberty.
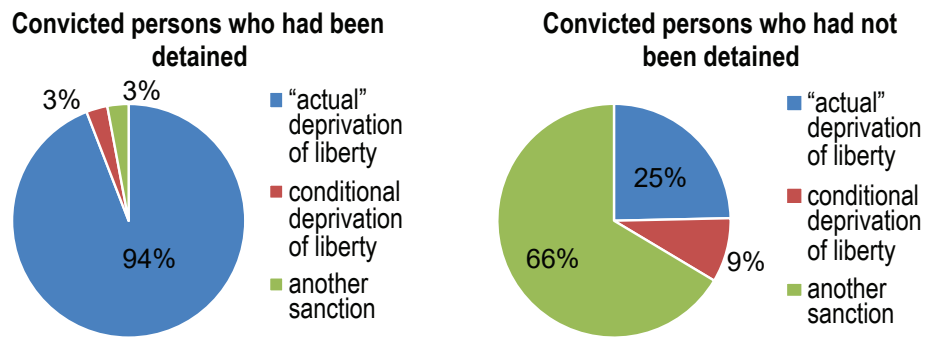

Figure 19

The fifth type of offence, whereof rulings were examined, concerned CL Section 195 (3), laundering of criminally acquired financial resources or other property, if this had been committed on a large scale or by an organised group, the applicable punishment for which is deprivation of liberty for the period from three to twelve years, with confiscation of property or without it, and with probationary supervision for the period of up to three years or without it.

In the database of anonymised court rulings for the respective period, rulings on sentencing five persons were available ${ }^{35}$. None of these persons had been applied pre-trial detention, and all of them, finally, were sentenced to deprivation of liberty, applying conditional sentencing.

The same situation was observed, regarding the persons, who had been convicted for in accordance to the sixth type of offence listed in CL, Section 260 (2), i.e., for violating traffic rules and provisions regarding vehicle operation, if committed by a person operating the vehicle and resulted in infliction of grave bodily injuries on the victim or causing a person's death. The applicable punishment thereof is deprivation of liberty for the period up to eight years, with revoking of the driver's licence for the period up to five years. Court rulings on sentencing 36 persons were examined $^{36}$. None of them had been applied pre-trial detention, and they were sentenced to conditional deprivation of liberty.

35 Rulings by district/municipal courts in criminal cases against persons charged with committing of the crime envisaged in CL Section 195 (3), which can be found on the site https://manas.tiesas.lv/ eTiesasMvc/eclinolemumi [last viewed November 1,2019].

To be searched according to the following ECLI numbers:

ECLI:LV:RVPT:2018:1108.15830004215.1.S; ECLI:LV:RVPT:2019:0306.11816005017.2.S; ECLI:LV:RVPT:2019:0322.11816012016.2.S;ECLI:LV:RIRT:2019:0328.11518019515.4.S

36 Rulings by district/municipal courts in criminal cases against persons charged with committing of the crime envisaged in CL Section 260 (2), which can be found on the site https://manas.tiesas.lv/ eTiesasMvc/eclinolemumi [last viewed November 1,2019].

Information about ECLI numbers of these cases can be found in the list "Legal practice: national" at the end of the article. 
Hence, assessing the impact of previous detention on the type of punishment and sanction, the following conclusion can be made: Observations made by professionals and the analysis of judgements point to the trend that detention has an independent impact on the type of punishment and sanction, and several judgements suggest that the judge's choice of the type of punishment and sanction had been influenced by the fact that the person had been detained. At the same time, absence of statistics and the majority of anonymised judgements only in an abbreviated form prohibits from conducting a fully objective comparison because, in a large part of cases, these judgements do not include the data that characterise a person, which precludes an objective assessment of whether the setting of the type of punishment and sanction had not been influenced by another factor.

\section{Conclusions}

1. In Latvia, there is a decreasing trend in the application of detention, as well as in the number of detained persons.

2. At the same time, many indicators, including those regarding the number of prison inmates per 10000 inhabitants in Latvia, statistically are above the median and also above the average indicator in Europe.

3. Researching the prevalence of detention, its impact on the final outcome of criminal proceedings, i.e., recognising person as guilty orexoneration, the type of applied punishment and sanction, is significantly hindered by the absence or incompleteness of statistics, unavailability of rulings made in the pre-trial proceedings for research, as well as the court judgements only in the abbreviated form, which do not provide sufficient information for making valid conclusions.

4. To a large extent, the subjective attitude towards the frequency of applying detention, the practical problems in its application, as well as its impact on the final outcome of criminal proceedings are determined by respondents' affiliation to the area of professional activities (the criminal procedural role).

5. The most significant and persisting problem in the practical application of detention is failure to present the investigation file, including the materials that justify detention, to the defence providers.

6. An assumption can be made that the fact of detention has an independent and significant impact on determining the type of punishment and sanction.

7. To confirm or reject the assumptions made in the current and other studies, research on a larger scale should be continued, with access to more detailed statistics and broader accessibility of criminal procedural documents, as well as communication with detained persons.

8. It would be necessary to continue researching the issues outlined in the article to form a more complete view on the practical application of detention in Latvia, which would be valuable for drafting the future law policy documents and improving the practice of law enforcement. 


\section{BIBLIOGRAPHY}

\section{Literature}

1. Aebi M. F. \& Tiago M. M. SPACE I - 2018 - Council of Europe Annual Penal Statistics: Prison populations. Strasbourg: Council of Europe. Available at: http://wp.unil.ch/space/ files/2019/06/FinalReportSPACEI2018_190611-1.pdf [last viewed November 1, 2019].

2. Dobbie W., Goldin J., Yang C. The Effects of Pre-Trial Detention on Conviction, Future Crime, and Employment: Evidence from Randomly Assigned Judges. The American Economic Review, Vol. 108, No. 2, 2018, pp. 201-240. Available at: https://pubs.aeaweb.org/doi/ pdf/10.1257/aer.20161503

3. Euvrard E., Leclerc C. Pre-trial detention and guilty pleas: Inducement or coercion? Punishment \& Society, 19(5), 2017, pp. 525-542. Available at: https://doi.org/ $10.1177 / 1462474516670153$ [last viewed November 1, 2019].

4. Hopkins B., Bains C. H., Doyle C. Principles of pretrial release: reforming bail without repeating its harms. Journal of Criminal Law \& Criminology, Vol. 108, Issue 4, 2018, pp. 679-700. Available at: http://datubazes.lanet.lv:3537/ehost/detail/detail?vid=0\&sid= fbbfdcb6-0155-4e0b-93ac-60c8e2409ae3\%40sdc-v-sessmgr02\&bdata=JnNpdGU9ZWhvc3 QtbGl2ZQ\%3d\%3d\#AN=135676927\&db=a9h [last viewed November 1, 2019].

5. Lee J. G. To Detain or Not to Detain? Using Propensity Scores to Examine the Relationship Between Pretrial Detention and Conviction. Criminal Justice Policy Review, 30(1), 2019, pp. 128-152. Available at: https://doi.org/10.1177/0887403416668016 [last viewed November 1, 2019].

6. Lippke R. L. Preventive Pre-trial Detention without Punishment. Res Publica, 20:111., 2014, p. 112 Available at: https://doi.org/10.1007/s11158-013-9234-6 [last viewed November 1, 2019].

7. Petersen N. Do Detainees Plead Guilty Faster? A Survival Analysis of Pretrial Detention and the Timing of Guilty Pleas. Criminal Justice Policy Review, 2019, pp. 1-21. Available at: https://doi.org/10.1177/0887403419838020 [last viewed November 1, 2019].

8. Pre-trial detention assessment tool. Available at: https://rm.coe.int/pre-trial-detentionassessment-tool/168075ae06 [last viewed November 1, 2019].

9. Sacks M., Ackerman A. R. Bail and Sentencing: Does Pretrial Detention Lead to Harsher Punishment? Criminal Justice Policy Review, 25(1), 2014, p. 62. Available at: https:// doi.org/10.1177/0887403412461501 [last viewed November 1, 2019].

10. Titaev K. D. Pretrial detention in Russian criminal courts: a statistical analysis. International Journal of Comparative and Applied Criminal Justice, 41: 3, 2017, pp. 145-161. Available at: 10.1080/01924036.2016.1239117 [last viewed November 1, 2019].

11. Van Kempen, M. Jendly (eds.) Overuse in Criminal Justice System. On Criminalization, Prosecution and Imprisonment. United Kingdom: Interesentia Ltd, 2019.

12. Zahars V. Kriminālpolitika: mūsdienu tendences un procesi [Criminal Policy: Contemporary Trends and Processes]. Daugavpils, Daugavpils universitātes Akadēmiskais apgāds, 2018.

\section{Legislative acts}

1. Criminal Law. Available at: https://likumi.lv/ta/en/en/id/88966 [last viewed November 1, 2019].

2. Criminal Procedure Law. Available at: https://likumi.lv/ta/en/en/id/107820 [last viewed November 1, 2019]. 
3. Law On the Procedures for Holding under Arrest. Available at: https://likumi.lv/ta/en/en/ id/138990 [last viewed November 1, 2019].

4. Sentence Execution Code of Latvia. Available at: https://likumi.lv/ta/en/en/id/90218 [last viewed November 1, 2019].

5. Brīvības atņemšanas iestādes iekšējās kārtības noteikumi [Internal Regulations of an Institution for Deprivation of Liberty]. Available at: https://likumi.lv/ta/id/136495-brivibasatnemsanas-iestades-ieksejas-kartibas-noteikumi [last viewed November 1, 2019].

6. Izmeklēšanas cietuma iekšējās kārtības noteikumi [Internal Regulations of a Remand Prison]. Available at: https://likumi.lv/ta/id/167184-izmeklesanas-cietuma-ieksejas-kartibas-noteikumi [last viewed November 1, 2019].

7. Council of Europe Parliamentary Assembly Resolution 2077 (2015)1 Abuse of pretrial detention in States Parties to the European Convention on Human Rights. Available at: http:// semantic-pace.net/tools/pdf.aspx?doc=aHR0cDovL2Fzc2VtYmx5LmNvZS5pbnQvbncveG 1sL1hSZWYvWDJILURXLWV4dHIuYXNwP2ZpbGVpZD0yMjIwNiZsYW5nPUVO\&xsl= aHR0cDovL3NlbWFudGljcGFjZS5uZXQvWHNsdC9QZGYvWFJIZi1XRC1BVC1YTUwy UERGLnhzbA==\&xsltparams=ZmlsZWlkPTIyMjA2 [last viewed November 1, 2019].

\section{Legal practice: international}

1. ECHR judgment of 3 November 2015 in case Mikselsons v. Latvia (Application No. 46413/10). Available at: http://hudoc.echr.coe.int/eng?i=001-158350 [last viewed November 1, 2019].

\section{Legal practice: national}

1. Rulings by district/municipal courts in criminal cases against persons charged with committing of the crime envisaged in CL Section 116, which can be found on the site https:// manas.tiesas.lv/eTiesasMvc/eclinolemumi [last viewed November 1, 2019]. To be searched according to the following ECLI numbers: ECLI:LV:RVPT:2018:1026.11087034718.2.S; EC LI:LV:KURT:2018:1102.11261082617.1.S; ECLI:LV:RIRT:2018:1128.11355004115.9.S; ECLI:LV:RIRT:2019:0201.11355012018.2.S; ECLI:LV:ZRT:2019:0304.11905008218.1.S; ECLI:LV:RIRT:2019:0429.11351015518.2.S

2. Rulings by district/municipal courts in criminal cases against persons charged with committing of the crime envisaged in CL Section 125 (3) , which can be found on the site https:// manas.tiesas.lv/eTiesasMvc/eclinolemumi [last viewed November 1, 2019].

To be searched according to the following ECLI numbers:

ECLI:LV:ZRT:2018:1004.11221129517.1.S; ECLI:LV:VRT:2018:1009.11280023314.2.S;

ECLI:LV:RPPT:2018:1011.11096198516.1.S; ECLI:LV:KURT:2018:1012.11151052217.1.S;

ECLI:LV:ZRT:2018:1015.11390028917.4.S; ECLI:LV:KURT:2018:1112.11261114117.2.S;

ECLI:LV:DAUT:2018:1203.11240048417.3.S; ECLI:LV:VRT:2018:1213.11280003618.1.S;

ECLI:LV:RVPT:2018:1221.11094080518.4.S; ECLI:LV:DAUT:2019:0116.11181152517.2.S;

ECLI:LV:RIRT:2019:0118.11353034518.3.S; ECLI:LV:DAUT:2019:0206.11181054718.1.S;

ECLI:LV:KURT:2019:0211.11250000818.4.S; ECLI:LV:RLPT:2019:0220.11088122518.2.S;

ECLI:LV:DAUT:2019:0225.11181113418.1.S; ECLI:LV:KURT:2019:0307.11261016216.5.S;

ECLI:LV:DAUT:2019:0508.11181060318.2.S; ECLI:LV:DAUT:2019:0613.11181116418.1.S 
3. Rulings by district/municipal courts in criminal cases against persons charged with committing of the crime envisaged in CL Section 177 (1), which can be found on the site https://manas.tiesas.lv/eTiesasMvc/eclinolemumi [last viewed November 1, 2019].

To be searched according to the following ECLI numbers:

ECLI:LV:KURT:2018:1017.11270002413.1.S; ECLI:LV:RVPT:2018:1024.11087099417.2.S; ECLI:LV:RVPT:2018:1030.11094001815.7.S; ECLI:LV:ZRT:2018:1217.11390039815.2.S; ECLI:LV:RLPT:2019:0110.15840124918.2.S; ECLI:LV:ZRT:2019:0114.12210000715.2.S; ECLI:LV:VRT:2019:0121.11300003916.3.S; ECLI:LV:KURT:2019:0123.11380039818.2.S; ECLI:LV:RVPT:2019:0124.11096190916.1.S; ECLI:LV:KURT:2019:0214.11380003317.1.S; ECLI:LV:KURT:2019:0225.11360042316.1.S; ECLI:LV:KURT:2019:0307.15830001917.2.S; ECLI:LV:RVPT:2019:0318.11815002917.2.S; ECLI:LV:RVPT:2019:0320.11087032817.2.S; ECLI:LV:ZRT:2019:0409.11221110917.3.S; ECLI:LV:DAUT:2019:0415.11181165918.1.S; ECLI:LV:RLPT:2019:0429.11088078816.2.S; ECLI:LV:ZRT:2019:0507.11221082517.1.S; ECLI:LV:ZRT:2019:0507.11120072116.3.S; ECLI:LV:RIRT:2019:0516.15840016218.2.S; ECLI:LV:ZRT:2019:0523.11370005419.1.S; ECLI:LV:RVPT:2019:0524.11087050315.3.S; ECLI:LV:KURT:2019:0619.11270002314.5.S; ECLI:LV:RIRT:2019:0627.11352035117.3.S; ECLI:LV:RVPT:2019:0628.11091138216.2.S; ECLI:LV:ZRT:2019:0709.11210096316.2.S; ECLI:LV:ZRT:2019:0823.11370081118.1.S

4. Rulings by district/municipal courts in criminal cases against persons charged with committing of the crime envisaged in CL Section 253 (1), which can be found on the site https://manas.tiesas.lv/eTiesasMvc/eclinolemumi [last viewed November 1, 2019].

To be searched according to the following ECLI numbers

ECLI:LV:RPPT:2019:0709.11519005419.2.S; ECLI:LV:VRT:2019:0715.11300017619.3.S; ECLI:LV:RPPT:2019:0717.11519008619.2.S; ECLI:LV:ZRT:2019:0719.11905010317.2.S; ECLI:LV:RLPT:2019:0725.11088077617.4.S; ECLI:LV:ZRT:2019:0731.11310018719.3.S; ECLI:LV:RIRT:2019:0805.11410005519.2.S; ECLI:LV:RLPT:2019:0809.11088087719.2.S; ECLI:LV:KURT:2019:0813.11261067019.1.S; ECLI:LV:RPPT:2019:0814.11095087319.2.S; ECLI:LV:KURT:2019:0814.11380055818.1.S; ECLI:LV:REZT:2019:0819.11903011319.2.S; ECLI:LV:RLPT:2019:0822.11088073019.2.S; ECLI:LV:RVPT:2019:0823.110910919192.S; ECLI:LV:RLPT:2019:0827.11815003219.2.S; ECLI:LV:RIRT:2019:0902.11353013819.3.S; ECLI:LV:RVPT:2019:0903.11091065219.2.S; ECLI:LV:KURT:2019:0905.11261016219.1.S; ECLI:LV:DAUT:2019:0911.11181185518.2.S; ECLI:LV:RIRT:2019:0916.15840027219.2.S; ECLI:LV:RLPT:2019:0522.11088011514.4.S; ECLI:LV:RLPT:2019:0522.11087031819.3.S; ECLI:LV:RLPT:2019:0527.11088213118.2.S; ECLI:LV:RLPT:2019:0528.11088307514.6.S; ECLI:LV:KURT:2019:0604.11270000719.2.S; ECLI:LV:RLPT:2019:0605.11087029719.2.S; ECLI:LV:RPPT:2019:0610.11815002918.2.S; ECLI:LV:RPPT:2019:0612.11095161818.3.S; ECLI:LV:RVPT:2019:0618.11091003319.1.S; ECLI:LV:KURT:2019:0618.11270003319.1.S; ECLI:LV:KURT:2019:0620.11250013919.2.S; ECLI:LV:ZRT:2019:0620.11310025818.3.S; ECLI:LV:ZRT:2019:0621.11310018319.2.S; ECLI:LV:RPPT:2019:0626.11095052519.2.S; ECLI:LV:ZRT:2019:0628.15840060519.2.S; ECLI:LV:RLPT:2019:0702.11089041119.2.S; 
ECLI:LV:VRT:2019:0702.11140035518.3.S; ECLI:LV:RPPT:2019:0703.11096029519.2.S; ECLI:LV:RLPT:2019:0705.11088235518.2.S; ECLI:LV:ZRT:2019:0408.11905007318.1.S; ECLI:LV:RPPT:2019:0409.11096209118.1.S; ECLI:LV:KURT:2019:0410.11270001219.2.S; ECLI:LV:KURT:2019:0411.11270004518.2.S; ECLI:LV:RLPT:2019:0415.11519015116.16.S; ECLI:LV:RPPT:2019:0415.11096231217.1.S; ECLI:LV:RIRT:2019:0416.11410021319.1.S; ECLI:LV:ZRT:2019:0423.11905002017.2.S; ECLI:LV:RLPT:2019:0424.11088237715.1.S; ECLI:LV:RLPT:2019:0424.11087123018.2.S; ECLI:LV:RPPT:2019:0430.11519010518.2.S; ECLI:LV:RLPT:2019:0430.11089007919.1.S; ECLI:LV:RLPT:2019:0502.11089080118.2.S; ECLI:LV:KURT:2019:0503.11270002419.1.S; ECLI:LV:KURT:2019:0507.11250008519.2.S; ECLI:LV:RLPT:2019:0508.13800008218.2.S; ECLI:LV:VRT:2019:0513.11904007618.2.S; ECLI:LV:ZRT:2019:0515.11310004617.2.S; ECLI:LV:RLPT:2019:0517.11088066015.3.S; ECLI:LV:DAUT:2019:0517.11181200718.1.S; ECLI:LV:RPPT:2019:0225.11096194518.2.S; ECLI:LV:RLPT:2019:0226.11088217415.2.S; ECLI:LV:DAUT:2019:0226.11903021618.1.S; ECLI:LV:RVPT:2019:0226.11815004218.2.S; ECLI:LV:ZRT:2019:0227.11310078517.2.S; ECLI:LV:RLPT:2019:0304.11088168518.2.S; ECLI:LV:VRT:2019:0304.11904000119.1.S; ECLI:LV:RVPT:2019:0304.11088025818.2.S; ECLI:LV:RLPT:2019:0305.11088035318.2.S; ECLI:LV:VRT:2019:0306.11400028918.1.S; ECLI:LV:KURT:2019:0308.11261094118.2.S; ECLI:LV:RPPT:2019:0312.11095125618.2.S; ECLI:LV:RPPT:2019:0314.11095083118.4.S; ECLI:LV:RVPT:2019:0321.11519000419.3.S; ECLI:LV:RLPT:2019:0325.11088159618.2.S; ECLI:LV:RLPT:2019:0328.11088175818.2.S; ECLI:LV:KURT:2019:0401.11261004719.1.S; ECLI:LV:RIRT:2019:0402.11410011419.2.S; ECLI:LV:RVPT:2019:0404.11087031119.2.S; ECLI:LV:RPPT:2019:0404.11096223617.4.S; ECLI:LV:RLPT:2019:0115.11088091718.2.S; ECLI:LV:DAUT:2019:0115.11181100217.3.S; ECLI:LV:DAUT:2019:0118.11181153418.2.S; ECLI:LV:RVPT:2019:0124.11088024617.1.S; ECLI:LV:RLPT:2019:0124.11088197617.2.S; ECLI:LV:RIRT:2019:0125.11410002619.1.S; ECLI:LV:ZRT:2019:0129.11905002318.2.S; ECLI:LV:ZRT:2019:0206.11210050818.1.S; ECLI:LV:RVPT:2019:0207.11087107418.2.S; ECLI:LV:KURT:2019:0211.13902000318.1.S; ECLI:LV:VRT:2019:0211.11400019418.1.S; ECLI:LV:ZRT:2019:0211.11390027618.2.S; ECLI:LV:VRT:2019:0218.11400042818.2S; ECLI:LV:RIRT:2019:0218.11410004319.3.S; ECLI:LV:KURT:2019:0219.15840130318.3.S; ECLI:LV:RLPT:2019:0220.11088228717.1.S; ECLI:LV:REZT:2019:0221.11331074518.1.S; ECLI:LV:DAUT:2019:0221.11181154918.1.S; ECLI:LV:RLPT:2019:0221.11519007718.5.S; ECLI:LV:KURT:2018:1219.11270007118.2.S; ECLI:LV:KURT:2018:1220.11261094418.2.S; ECLI:LV:RVPT:2018:1221.11094103818.2.S; ECLI:LV:KURT:2018:1227.11261094518.2.S; ECLI:LV:KURT:2018:1227.11380048218.1.S; ECLI:LV:RPPT:2018:1228.11096199818.2.S; ECLI:LV:KURT:2018:1228.11380054318.2.S; ECLI:LV:RLPT:2019:0102.11519012918.2.S; ECLI:LV:RLPT:2019:0102.11088046115.2.S; ECLI:LV:KURT:2019:0102.11270007018.2.S; ECLI:LV:ZRT:2019:0104.11370010317.3.S; ECLI:LV:RVPT:2019:0107.11091014717.4.S; ECLI:LV:RPPT:2019:0107.11096055818.2.S; ECLI:LV:RVPT:2019:0107.11815004418.2.S; ECLI:LV:DAUT:2019:0107.11903013218.4.S; ECLI:LV:REZT:2019:0108.11331011216.2.S; ECLI:LV:RLPT:2019:0108.11095148817.2.S; ECLI:LV:RIRT:2019:0114.11410044218.2.S; 
ECLI:LV:DAUT:2019:0114.11181086718.1.S; ECLI:LV:RLPT:2019:0114.11088125918.1.S; ECLI:LV:RIRT:2018:1114.11410032518.2.S; ECLI:LV:KURT:2018:1114.11261068018.2.S; ECLI:LV:KURT:2018:1114.11250025818.2.S; ECLI:LV:REZT:2018:1114.11290037718.2.S; ECLI:LV:RLPT:2018:1115.11089086418.2.S; ECLI:LV:RVPT:2018:1116.11091141618.2.S; ECLI:LV:ZRT:2018:1116.11310094317.2.S; ECLI:LV:REZT:2018:1128.11331015318.3.S; ECLI:LV:RVPT:2018:1203.11087133717.2.S; ECLI:LV:RIRT:2018:1203.11410039418.1.S; ECLI:LV:RLPT:2018:1204.11088012818.4.S; ECLI:LV:ZRT:2018:1204.11905008118.2.S; ECLI:LV:DAUT:2018:1204.11181120818.1.S; ECLI:LV:RIRT:2018:1204.13800019516.1.S; ECLI:LV:DAUT:2018:1204.11903006718.1.S; ECLI:LV:RLPT:2018:1205.11089153818.1.S; ECLI:LV:KURT:2018:1210.11270005318.1.S; ECLI:LV:RLPT:2018:1210.11088123017.2.S; ECLI:LV:RLPT:2018:1212.11089159817.4.S; ECLI:LV:KURT:2018:1219.11270006818.2.S; ECLI:LV:RPPT:2018:1023.11095188117.2.S; ECLI:LV:RLPT:2018:1025.11088018818.2.S; ECLI:LV:KURT:2018:1025.11261068118.2.S; ECLI:LV:RLPT:2018:1029.11087117018.2.S; ECLI:LV:VRT:2018:1030.11280002918.2.S; ECLI:LV:RVPT:2018:1031.11091138518.2.S; ECLI:LV:RLPT:2018:1101.11089044318.2.S; ECLI:LV:RLPT:2018:1101.11089094318.4.S; ECLI:LV:REZT:2018:1102.11290036818.1.S; ECLI:LV:ZRT:2018:1102.11905000918.2.S; ECLI:LV:RLPT:2018:1105.11088087718.2.S; ECLI:LV:RLPT:2018:1105.11087078818.4.S; ECLI:LV:RLPT:2018:1106.11088012918.1.S; ECLI:LV:REZT:2018:1107.11331059218.3.S; ECLI:LV:RPPT:2018:1108.11095133018.2.S; ECLI:LV:RLPT:2018:1108.11088126718.2.S; ECLI:LV:RPPT:2018:1109.11089151617.2.S; ECLI:LV:DAUT:2018:1109.11181162417.1.S; ECLI:LV:RIRT:2018:1113.11353030617.1.S; ECLI:LV:RLPT:2018:1113.11087109116.2.S; ECLI:LV:RPPT:2018:1002.11096295017.2.S; ECLI:LV:RLPT:2018:1002.11904004118.2.S; ECLI:LV:ZRT:2018:1002.11905010417.1.S; ECLI:LV:RPPT:2018:1002.11096265417.2.S; ECLI:LV:RPPT:2018:1003.11095112917.4.S; ECLI:LV:RIRT:2018:1003.11410062218.1.S; ECLI:LV:ZRT:2018:1003.11905003318.1.S; ECLI:LV:RVPT:2018:1004.11096193712.2.S; ECLI:LV:DAUT:2018:1008.11903000518.1.S; ECLI:LV:KURT:2018:1008.11261068218.2.S; ECLI:LV:VRT:2018:1008.11130016118.1.S; ECLI:LV:DAUT:2018:1009.11903011118.1.S; ECLI:LV:DAUT:2018:1009.11320023018.1.S; ECLI:LV:RVPT:2018:1016.11087087818.3.S; ECLI:LV:DAUT:2018:1017.11181006518.1.S; ECLI:LV:RLPT:2018:1017.11095135318.1.S; ECLI:LV:RLPT:2018:1022.11904007017.2.S; ECLI:LV:KURT:2018:1001.11380032618.1.S.

5. Rulings by district/municipal courts in criminal cases against persons charged with committing of the crime envisaged in CL Section 195 (3), which can be found on the site https://manas.tiesas.lv/eTiesasMvc/eclinolemumi [last viewed November 1, 2019].

To be searched according to the following ECLI numbers:

ECLI:LV:RVPT:2018:1108.15830004215.1.S; ECLI:LV:RVPT:2019:0306.11816005017.2.S; ECLI:LV:RVPT:2019:0322.11816012016.2.S; ECLI:LV:RIRT:2019:0328.11518019515.4.S.

6. Rulings by district/municipal courts in criminal cases against persons charged with committing of the crime envisaged in CL Section 260 (2), which can be found on the site https://manas.tiesas.lv/eTiesasMvc/eclinolemumi [last viewed November 1, 2019].

To be searched according to the following ECLI numbers:

ECLI:LV:RVPT:2018:1002.11520025717.1.S; ECLI:LV:RVPT:2018:1003.11520044816.2.S; ECLI:LV:RVPT:2018:1008.11520049417.2.S; ECLI:LV:RIRT:2018:1016.11520082817.2.S; 
ECLI:LV:ZRT:2018:1018.11390003718.2.S; ECLI:LV:RLPT:2018:1022.11520083017.2.S; ECLI:LV:RPPT:2018:1106.11520085116.2.S; ECLI:LV:KURT:2018:1112.11151072117.1.S; ECLI:LV:RLPT:2018:1113.11520091816.1.S; ECLI:LV:REZT:2018:1203.11290023717.2.S; ECLI:LV:RIRT:2018:1204.11520047417.2.S; ECLI:LV:DAUT:2018:1206.11320009318.1.S; ECLI:LV:RIRT:2018:1211.11520060417.2.S; ECLI:LV:RIRT:2018:1213.11520025618.2.S; ECLI:LV:DAUT:2018:1214.11320052717.1.S; ECLI:LV:ZRT:2018:1218.11390085717.2.S; ECLI:LV:KURT:2019:0116.11360026417.1.S; ECLI:LV:ZRT:2019:0128.11370032818.2.S; ECLI:LV:RPPT:2019:0225.11520053918.1.S; ECLI:LV:VRT:2019:0304.11400037717.5.S; ECLI:LV:KURT:2019:0321.11250016218.2.S; ECLI:LV:RIRT:2019:0401.11520005218.2.S; ECLI:LV:RVPT:2019:0403.11520006518.2.S; ECLI:LV:ZRT:2019:0425.11310078718.3.S; ECLI:LV:RVPT:2019:0513.11520012418.1.S; ECLI:LV:ZRT:2019:0514.11310072017.7.S; ECLI:LV:KURT:2019:0515.11261093418.2.S; ECLI:LV:RLPT:2019:0520.11520066018.2.S; ECLI:LV:ZRT:2019:0522.11370033018.2.S; ECLI:LV:DAUT:2019:0605.11181130318.1.S; ECLI:LV:RPPT:2019:0605.11520082418.2.S; ECLI:LV:RLPT:2019:0617.11520001618.2.S; ECLI:LV:KURT:2019:0711.11380005319.2.S; ECLI:LV:ZRT:2019:0812.11310043018.2.S

\section{Other sources: statistics}

1. Centrālās statistikas pārvaldes statistikas dati par cietumos esošajām personām [Data of the Central Statistical Bureau on Persons in Prisons]. Available at: https://www.csb.gov.lv/ lv/statistika/statistikas-temas/socialie-procesi/likumparkapumi/tabulas/skg090/cietumosesoso-personu-skaits-gada-beigas [last viewed November 1, 2019].

2. Iekšlietu ministrijas Informācijas centra Statistika par personām, kurām ir tiesības uz aizstāvību [Statistics of the Information Centre of the Ministry of the Interior on persons having the right to defence]. Available at: https://www.ic.iem.gov.lv/lv/node/769 [last viewed November 1, 2019].

3. Ieslodzijuma vietu pārvaldes statistikas dati par 2018. gadu [Statistical data of the Prison Administration on 2018]. Available at: http://www.ievp.gov.lv/index.php/publikacijas/ statistika [last viewed November 1, 2019].

4. Statistiskā informācija par LR prokuratūras darbības rezultātiem 2018. gadā [Statistical information on the performance outcomes of the Prosecutor's Office of the Republic of Latvia in 2018]. Available at: http://www.prokuratura.gov.lv/lv/noderigi/gada-parskati [last viewed November 1, 2019]. 